\title{
Fungsi Dewan Perwakilan Rakyat Daerah Dalam Pengawasan Kebijakan Daerah (Studi Kasus: Kantor DPRD Kabupaten Buton)
}

\author{
La Asiri1 \\ 1Program Studi Ilmu Pemerintahan, Fakultas Ilmu Sosial dan Ilmu Politik \\ Universitas Muhammadiyah Buton, Jl. Betoambari No. 36 Baubau \\ E-mail: laasiriaris72@gmail.com
}

\begin{abstract}
Abstrak: Penelitian ini bertujuan untuk mengetahui salah satu fungsi DPRD dalam melakukan pengawasan terhadap kebijakan daerah sekaligus untuk mengjkaji sejumlah faktor yang memengaruhi fungsi DPRD dalam menjalankan pengawasan terhadap kebijakan daerah Kabupaten Buton. Jenis penelitian ini menggunakan desain deskriptif kualitatif dimana prosedur pemecahan masalah yang diselidiki dengan menggambarkan atau melukiskan keadaan subjek atau objek penelitian. Penelitian ini menunjukan bahwa fungsi DPRD pada proses pengawasan kebijakan daerah, melalui proses diantaranya yaitu penyusunan Anggaran Pendapatan dan Belanja Daerah (APBD), pelaksanaan kebijakan daerah, dan pertanggung jawaban terhadap kebijakan daerah oleh eksekutif (evaluasi). Selain itu, terdapat beberapa faktor yang memmengaruhi pelaksanaan fungsi legislasi tersebut dalam melakukan pengawasan kebijakan daerah yaitu kompetensi anggota DPRD, ketersediaan sarana dan prasarana, serta ketepatan waktu dalam melakukan pengawasan.
\end{abstract}

Kata Kunci: Fungsi, Pengawasan, DPRD

Abstrac: This study aims to determine one of the functions of the DPRD in supervising regional policies as well as to examine a number of factors that influence the function of the DPRD in carrying out oversight of Buton Regency regional policies. This type of research uses a qualitative descriptive design where problem solving procedures are investigated by describing or describing the state of the subject or object of research. This study shows that the function of the DPRD in the process of supervising regional policies, through processes including the preparation of the Regional Budget (APBD), implementation of regional policies, and accountability to regional policies by the executive (evaluation). In addition, there are several factors that influence the implementation of the legislative function in supervising regional policies, namely the competence of DPRD members, the availability of facilities and infrastructure, and the timeliness in conducting supervision.

Keywords: Function, Oversight, DPRD 


\section{Pendahuluan}

Pemerintahan daerah yang baik (good local government) merupakan isu yang paling mengemuka dalam pengelolaan administrasi public dewasa ini. Tuntutan masyarakat kepada pemerintah terhadap pelaksanaan penyelenggaraan pemerintahan daerah yang baik sejalan dengan semakin meningkatnya pengetahuan masyarakat, disamping adanya pergeseran paradigm pemerintahan dari rulling government yang terus bergerak menuju good governance dipahami sebagai fenomena berdemokrasi secara adil. Dalam konteks ini diperlukan peran dan fungsi Dewan Perwakilan Rakyat Daerah (DPRD) yang kuat, aspiratif, dan berkarakter. DPRD sebagai wakil rakyat, senantiasa memperhatikan dan memperjuangkan aspirasi masyarakat di daerah, sesuai dengan tugas pokok dan fungsinya.

Salah satu prinsip dasar otonomi daerah menurut Undang-Undang Nomor 32 Tahun 2004, revisi melalui Undang-Undang Nomor 23 Tahun 2014 adalah pelaksanaan otonomi daerah harus lebih meningkatkan peran dan fungsi badan legislative daerah, baik fungsi legislasi, fungsi budgeting, maupun fungsi pengawasan atas penyelenggaraan pemerintahan daerah yang efektif dan akuntabel. Hal ini menunjukkkan bahwa DPRD dalam konteks UU No. 23 Tahun 2014 benar-benar harus diberdayakan secara optimal melalui pemberian tugas, hak, dan wewenang yang luas sehingga DPRD dapat melakukan fungsinya dengan maksimal sebagai penyalur aspirasi masyarakat dalam rangka pembangunan demokrasi local.
Sebagai lembaga perwakilan di daerah, DPRD mempunyai fungsi yang sangat besar dalam mewarnai jalannya pemerintah daerah otonom. Dengan peran demikian,aspek responsibilitas dalam pelaksanaan tugas menjadi salah satu factor penentu dalam memaknai dan memberikan manfaat terhadap jalannya pemerintahan di daerah guna mewujudkan masyarakat yang sejahtera dan berdaulat. Pemahaman ini sekaligus menyajikan pandangan bahwa lembaga legislative perlu terus mengembangkan dirinya, dan hal ini tidak terlepas dari dinamika kualitas infrastruktur public, hubungan dengan lembaga lainnya dalam bingkai nilai-nilai pemerintahan nasional.

DPRD sebagai lembaga legislative daerah mempunyai tiga fungsi utama yaitu: 1) fungsi legislasi, 2) fungsi anggaran, dan 3) fungsi pengawasan. Fungsi pengawasan yang dilakukan oleh DPRD adalah pengawasan terhadap pelaksanaan berbagai kebijakan publik daerah yang dilaksanakan oleh oleh lembaga eksekutif termasuk didalamnya pengawasan terhadap kebijakan pelaksanaan APBD. Fungsi pengawasan ini sangat penting bagi DPRD untuk lebih aktif dan kreatif menyikapi berbagai kendala terhadap pelaksanaan perda. Melalui pengawasan oleh DPRD, eksekutif sebagai pelaksana kebijakan akan terhindar dari berbagai penyimpangan dan penyelewengan. Dari hasil pengawasan DPRD akan diambil tindakan penyempurnaan dalam memperbaiki pelaksanaan kebijakan tersebut.

Jika kita melihat sepak terjang pelaksanaan tugas dan fungsi DPRD 
Kabupaten Buton sebagai lembaga legislative daerah khususnya yang berhubungan dengan fungsi pengawasan kepada eksekutuf, nampaknya masih terdapat sejumlah masalah karena kurang efektifnya pengawasan. Ada sejumlah temuan masyarakat di lapangan seperti pembangunan gedung sekolah yang tidak sesuai RAB, pembangunan beberapa jembatan di Kecamatan Lasalimu dengan APBD tahun 2015-2016 yang pengerjaanya sampai sekarang belum selesai. Masalah ini menjadi indikasi awal tentang masih lemahnya pengawasan kebijakan daerah yang dilakukan oleh DPRD Kabupaten Buton kepada eksekutif.

Berdasarkan uraian latar belakang di atas, maka focus penelitian ini adalah bagaimana fungsi Dewan Perwakilan Rakyat Daerah (DPRD) dalam melakukan pengawasan terhadap kebijakan daerah melalui studi kasus pada kantor DPRD Kabupaten Buton?

Tujuan penelitian ini adalah untuk menganalisis fungsi pengawasan DPRD Kabupaten Buton terhadap pelaksanaan kebijakan daerah.

\section{Metode Penelitian}

Metode penelitian yang digunakan adalah pendekatan deskriptif kualitatif sebagai suatu metode yang dikerjakan untuk mengungkap gejala-gejala secara holistickontekstual, melalui pengumpulan data dari latar alami sebagai sumber dengan instrument kunci peneliti itu sendiri, (Suyitno, 2006: 5).
Terkait dengan penelitian ini, pendekatan dekskriptif kualitatif membawa penulis untuk mengumpulkan data sebanyak mungkin mengenai fungsi DPRD dalam pengawasan kebijakan daerah. Selain itu pula, pemilihan dan penggunaan metode analisis kualitatif dalam konteks penelitian ini, dilaksanakan untuk mengetahui dan mendeskripsikan fungsi DPRD dalam pengawasan kebijakan daerah.

\section{Pembahasan}

\section{a. Perencanaan (Penyusunan APBD)}

Proses penyusunan Anggarana Pendapatan dan Belanja Daerah Kabupaten Buton diawali dengan proses penentuan rencana pagu APBD sesuai siklus anggaran dimulai: 1) proses penentuan penerimaaan daerah, 2) proses penentuan belanja rutin, dan 3) proses penentuan belanja pembangunan atau belanja modal.

Selanjutnya hasil rencana annggaran yang telah disusun secara terpadu diajukan kepada kepala daerah untuk mendapat persetujuan dan RAPBD tersebut diserahkan kepada DPRD untuk dilakukan pembahasan bersama eksekutuf (SKPD terkait). Dalam pembahasan RAPBD ini, diharapkan pihak legislative dapat memberikan komentar, masukan, tanggapan, dan ususl kepada eksekutif melalui dokumen kebijakan pembangunan tahunan dan kebijakan anggaran tahunan yang telah disepakati sebelumnya.

Pada tahap ini DPRD memiliki peran dalam melalukan kegiatan: 1) menampung dan menyalurkan aspirasi masyarakat, 2) memberikan petunjuk dan arah kebijakan 
tentang APBD serta menentukan strategi dan prioritas dari APBD tersebut, 3) melakukan klarifikasi dan ratifikasi (diskusi APBD dalam rapat paripurna), dan 4) mengambil keputusan secara kolektif kolegial.

Pada tahap agregasi, anggota DPRD mempunyai beberapa cara yang dapat dilakukan untuk memperoleh informasi dari masyarakat diantaranya usul eksekutif melalui hasil musrembang.

Eksekutif terkadang tidak menjadikan prioritas kebutuhan masyarakat melalui hasil musrembang. Hal ini disebabkan karena pemerintah daerah kabupaten Buton telah mempunyai program tersendiri dalam menentukan arah pemabngunan satu tahun kedepan sehingga apa yang menjadi kebutuhan masyarakat terabaikan begitu saja.

Bahkan berdasarkan hasil wawancara dengan salah seorang tokoh masyarakat kabupaten Buton, La Maki, diperoleh informasi bahwa aspir asi masyarakat yang disampaikan melalui kegiatan musrembang belum secara maksimal ditanggapi dan ditindaklanjuti oleh anggota DPRD. Yang ironis adalah kegiatan musrembang sejatinya sebagai sarana untuk menampung dan memperoleh aspirasi masyarakat secara luas dan terbuka justru hanya sebatas memenuhi ketentuan formal-normatif belaka. Di sisi lain, anggaran yang dikeluarkan untuk penyelenggaraan satu kegiatan musrembang dalam setiap tahun anggaran mencapai Rp. 1.500.000.000,- (satu milyar lima ratus juta rupiah). Angka yang terbilang cukup besar ini tidak berbanding lurus dengan hasil musrembang dalam menyerap aspirasi masyarakat dari berbagai kelompok dan golongan.

Dengan demikian dapat ditarik kesimpulan sementara, bahwa anggota DPRD belum memiliki kepekaan dan responsibilitas yang tinggi dalam menyerap, menampung, dan mengakomodasi setiap aspirasi masyarakat yang diwakilinya. Hal ini pada akhirnya akan membawa dampak dan pengaruh pada tahap penetapan petunjuk dan kebijakan publik tentang politik anggaran, penentuan strategi dan skala prioritas dari APBD tersebut.

Tahap ratifikasi merupakan tahap yang melibatkan proses politik yang cukup rumit antara eksekutif dan legislative daerah. Pimpinan eksekutif (kepala daerah) dituntut tidak hanya memiliki "managerial skill" tetapi juga harus memiliki "political skill", "salesmanship", dan "condition building" yang memadai. Integritas dan kesiapan mental yang tinggi dari eksekutif sangat penting dalam tahap ini. Dalam konteks ini, pimpinan eksekutif harus memiliki kemampuan untuk menjawab dan memberikan argumentasi yang rasional atas segala pertanyaan, sanggahan, dan bantahan dari pihak legislative.

Setelah proses pembahasan bersama antara eksekutif dengan legislatif, selanjutnya semua argumentasi yang sudah diperdebatkan di masing-masing komisi akan bermuara pada paripurna yang disahkan melalui keputusan ketua DPRD Kabupaten Buton sekaligus ini menandai akhir dari proses penyusunan dan penetapan Anggaran Pendapatan dan Belanja Daerah Kabupaten Buton. 


\section{b. Pengawasan Kebijakan Daerah}

Agar fungsi pengawasan dapat berjalan efektif dan efisisen, perlu adanya pengorganisasian proses yang baik dan terarah. Tahap demi tahap pengawasan dituangkan dalam bentuk rencana kerja disertai dengan penjadwalan serta keterlibatan berbagai pihak dari dalam maupun luar DPRD. Produk akhir dari proses pengawasan ini adalah rekomendasi yang harus disikapi oleh eksekutif. Pengawasan anggaran meliputi seluruh siklus anggaran. Secara sederhana pengawasan anggaran merupakan proses pengawasan terhadap kesesuaian perencanaan anggaran dan realisasi kegiatan pembangunan dengan tingkat transparansi, akuntabilitas, dan aksesibilitas yang tinggi, baik yang dilakukan oleh anggota DPRD maupun yang dilakukan oleh anggota masyarakat dalam masa satu tahun angggaran.

Program pengawasan oleh anggota DPRD Kabupaten Buton sudah menunjukkan langkah maju, hal ini dapat dibuktikan dengan data penelitian pada tahun 2015 dimana anggota DPRD Kabupaten Buton telah melakukan kunjungan kerja sebanyak 52 kali pada basis konstituen masing-masing daerah pemilihan. Kunjungan kerja sebanyak itu masuk dalam kategori baik dari sisi pengawasan keuangan daerah. Namun hal lain yang perlu diperdalam adalah tingginya intensitas kunjungan anggota DPRD ini hendaknya dapat membawa dampak positif terhadap konsekuensi pelaksanaan anggaran yang benar-benar sesuai dengan tuntutan dan harapan masyarakat secara luas. Dengan demikian, penggunaan anggaran yang efektif, efisien, dan proporsional akan sejalan dengan tujuan penyelenggaraan otonomi daerah yakni meningkatnya kesejahteraan masyarakat di daerah dapat tercapai.

Fakta lain yang sedikit berbeda dalam konteks pengawasan anggaran oleh anggota DPRD Kabupaten Buton seperti yang diungkapkan oleh salah seorang tokoh masyarakat, Drs. La Binci, bahwa anggota DPRD dalam melakukan kunjungan kerja dan inspeksi lapangan jika ada informasi yang diperoleh dari masyarakat, baik kelompok maupun individu. Hal tersebut terjadi karena anggota DPRD beralasan bahwa sesuai ketentuan Tata Tertib DPRD Kabupaten Buton pasal 146 ayat (1) menyatakan "pimpinan DPRD, alat kelengkapan DPRD, anggota DPRD atau fraksi di DPRD menerima, menampung, menyerap, dan menindaklanjuti pengaduan dan/atau aspirasi masyarakat yang disampaikan secara langsung atau tertulis tentang suatu permasalahan, sesuai dengan tugas, fungsi, dan wewenang DPRD. Kemudian dalam ayat (5) dinyatakan bahwa " dalam hal diperlukan, pengaduan dan/atau aspirasi masyarakat dapat ditindaklanjuti dengan: a) rapat dengar pendapat umum, b) rapat dengar pendapat, c) kunjungan kerja atau, d) rapat kerja alat kelengkapan DPRD dengan mitra kerjanya. Tata cara penerimaan dan tindak lanjut pengaduan dan/atau aspirasi masyarakat diatur oleh sekretaris DPRD dengan persetujuan pimpinan DPRD. 


\section{c. Pertanggungjawaban Pengawasan Kebijakan Daerah}

Dalam tata tertib DPRD Kabupaten Buton pasal 109 menyatakan bahwa: "selambat-lambatnya pertengahan bulan Juni tahun anggaran berjalan, bupati wajib menyampaikan rancangan Kebijakan Umum APBD (KUA) dan rancangan Prioritas dan Platform Anggaran Sementara (PPAS) tahun berikutnya kepada DPRD. Oleh sebab itu, berdasarkan tatib tersebut seharusnya eksekutif dalam hal ini bupati segera menyampaikan rancangan prioritas dan platform anggaran sementara, namun kewajiban tersebut terkadang tidak terlaksana sesuai estimasi waktu yang telah ditetapkan.

Kondisi ini dengan jelas dipaparkan oleh Lisna, SH, salah seorang anggota DPRD Kabupaten Buton dari Partai Nasdem, dimana agenda untuk menyampaikan rancangan prioritas dan platform anggaran sementara pada tahun 2016 tertunda sampai memasuki bulan September. Molornya penyampaian PPAS oleh bupati pada akhirnya berdampak pada kurang efektifnya pembahasan anggaran oleh DPRD karena mengingat ketrbatasan waktu yang tersedia. Di sisi lain, tatib DPRD Kabupaten Buton pasal 110 menyatakan bahwa" paling lambat minggu pertama bulan Oktober tahun anggaran sebelumnya dan tahun yang direncanakan, bupati wajib menyampaikan Rancangan Anggaran Pendapatan dan Belanja Daerah beserta lampirannya kepada DPRD untuk mendapatkan persetujuan bersama. Sempitnya waktu yang tersedia mengakibatkan pembahasan RAPBD tahun 2016 menjadi kurang maksimal.

Apa yang ingin di dorong dalam peraturan tersebut adalah agar public dapat mengakses berbagai informasi terkait rencana pemerintah daerah melalui pembahasan RAPBD oleh DPRD dalam satu tahun anggaran. Meskipun demikian, tidak dapat dipungkiri jika selama ini masyarakat sulit sekali memperoleh akses informasi mengenai kinerja anggota DPRD dalam mengagregasi kepentingan masyarakat. Hal ini pula yang membuat persepsi public terhadap anggota DPRD menjadi rendah.

Salah seorang tokoh masyarakat Kabupaten Buton, La Maki, menjelaskan persoalan aksesibitas public terhadap kinerja anggota DPRD sebagai berikut:

"Selama ini apa yang dilakukan oleh anggota DPRD masyarakat tidak mengetahui, baik itu tentang pertanggung jawaban dewan atau berapa besarnya anggaran, dan masih banyak lagi yang lain. Kita sebagai anggota masyarakat tidak mengetahui hal tersebut karena kita memang tidak pernah diundang kalau ada pembahasan seperti itu. Karena itu pula kami menjadi apatis akan hal tersebut".

Dari hasil wawancara di atas dapat disimpulkan bahwa masyarakat tidak pernah dilibatkan dalam pembahasan yang sangat krusial menyangkut platform anggaran yang sangat menentukan besaran, cakupan, arah, dan strategi pembangunan selama tahun anggaran berjalan. Terlebih dalam Tatib DPRD Kabupaten Buton 2015, tidak dicantumkan satu pun pasal tentang keikutsertaan masyarakat dalam pembahasan berbagai isu strategis daerah, 
rancangan peraturan daerah, rancangan APBD maupun pertanggung jawaban eksekutif dihadapan dewan.[

Mekanisme pertanggung jawaban dalam hal pengawasan DPRD dapat dilakukan dalam bentuk:

1. Pengawasan individual yang terencana dalam bentuk kegiatan reses dengan pola penganggaran yang sudah baku, sehingga pertanggung jawabannya juga sudah baku. Setiap anggota DPRD dibebankan membuat laporan hasil pengawasan (selama reses) dan disampaikan kepada pimpinan DPRD, baik melalui surat resmi yang ditembuskan kepada setiap anggota, fraksi, komisi, termasuk secretariat dewan dan media massa maupun dalam sidang paripurna anggota DPRD.

2. Pertanggungjawaban hasil pengawasan komisi biasanya dilaksanakan melalui rapat rutin mingguan internal anggota komisi yang biasa disebut rapat kerja mingguan komisi. Meski demikian secara kelembagaan berdasarkan tata tertib DPRD diagendakan rapat pleno untuk tiga bulan masa sidang. Dalam forum ini, masing-masing anggota DPRD melalui sidang pleno akan menyampaikan hasil kinerja selama tiga bulan masa sidang.

3. Hal yang sama dengan hasil pengawasan yang dilakukan gabungan komisi dan/atau anggota pansus, dan hasilnya ditujukan kepada pimpinan DPRD.

4. Hasil pengawasan, baik individu, komisi, gabungan komisi serta pansus juga dapat dipertanggung jawabkan melalui rapat pimpinan yang diperluas.

5. Hasil pengawasan DPRD bisa dipertanggung jawabkan melalui sidang paripurna atau dengan melibatkan masyarakat luas melalui forum evaluasi tahun masa sidang DPRD.

6. Disamping itu penting diperhatikan bagaimana hasil pengawasan tersebut terdokumentasi dalam bentuk laporan yang bagus dan terkelola dengan baik serta mudah dan murah untuk diakses oleh publik.

Pengawasan individual yang dilakukan orang per orang nampaknya lebih efektif bila dibandingkan dengan pengawasan yang dilakukan oleh kelompok dalam hal ini komisi. Pengawasan individual dapat dilakukan dengan melihat langsung kondisi masyarakat yang berada dalam daerah pemilihannya. Masa reses merupakan kesempatan bagi anggota DPRD untuk bertemu langsung dengan konstituen di lapangan, mengetahui persoalan-persoalan pembangunan, dan dari hasil reses ini akan disampaikan kepada pimpinan DPRD, baik melalui surat resmi yang ditembuskan langsung kepada fraksi dan komisi, bahkan jika temuan di lapangan merupakan masalah yang cukup serius untuk sesegera mungkin diatasi, anggota DPRD dapat meminta langsung untuk dilakukan rapat resmi fraksi sebagai bentuk pengawasan dan pertanggung jawaban mereka kepada konstituen. 


\section{Factor-Faktor yang Mempengaruhi Pelaksanaan Fungsi Pengawasan DPRD Kabupaten Buton terhadap Kebijakan Daerah}

Dalam UU No. 23 Tahun 2014 dijelaskan bahwa DPRD dapat melakukan pengawasan terhadap penyelenggaraan pemerintahan daerah dan pengelolaan Badan Usaha Milik Daerah (BUMD) serta usaha lainnya. Aktivitas yang dilakukan adalah dengan melakukan pemeriksaan, pengujian, dan penilaian atas kinerja perangkat daerah serta Badan Usaha Milik Daerah (BUMD).

Terdapat beberapa factor yang mempengaruhi optimaslisasi pelaksanaan pengawasan DPRD terhadap penyelenggaraan pemerintahan daerah, antara lain:

\section{a. Kualitas Anggota DPRD}

Penyelenggaraan pengawasan pemerintahan daerah dapat terlaksana dengan baik jika ditunjang oleh anggota dewan yang berkualitas, memiliki kecakapan dan kemampuan intelektual yang memadai, memahami fungsi dan mekanisne kerja kedewanan, serta mampu menterjemahkan aturan dan kebijakan serta regulasi daerah dalam menjalankan program yang telah disepakati dalam APBD.

b. Dukungan Sarana dan Prasarana

Dalam rangka memperkuat pengawasan terhadap kebijakan pemerintah daerah, diperlukan dukungan sarana dan prasarana yang memadai seperti gedung perkantoran yang representative, perangkat computer dan jaringan IT yang tersedia satu kali dua puluh empat jam, kendaraan operasional, dan lain-lain. Keterbatasan sarana dan prasarana yang tersedia membuat kinerja anggota DPRD menjadi lamban dan kurang maksimal.

\section{c. Ketepatan Waktu}

Salah satu factor yang menyebabkan kurang efektifnya pengawasan DPRD terhadap kinerja pemerintah daerah adalah adanya keterlambatan dalam melakukan pemeriksaan dan pengujian data yang akan dijadikan sebagai dasar dalam melakukan penyelidikan terhadap dugaan pelanggaran yang dilakukan oleh eksekutif.

Fenomena ini sejalan dengan indicator penilaian pelaksanaan fungsi pengwasan sebagaimana yang dikemukakan oleh Sarwoto (2010), bahwa suatu pelaksanaan pengawasan yang efektif jika ditunjang oleh ketepatan waktu, obyektif, realitas, terfokus, unsure keakuratan data dan terkoordinasi.

\section{Simpulan}

Dalam pelaksanaan peran dalam pengawasan kebijakan daerah, terdapat beberapa elemen yang menjadi pedoman bagi DPRD Kabupaten Buton dalam mewujudkan sistem pengawasan yang obyektif, akurat, dan akuntabel yakni: melalui penyusunan Anggaran Pendapatan dan Belanja Daerah yang berbasis pada urgensi kepentingan masyarakat daerah; pelaksanaan kebijakan daerah yang selalu dikontrol melalui mekanisme rapat dengar pendapat, rapat fraksi, dan rapat komisi; serta pengawasan pada saat pertanggungjawaban oleh pemerintah daerah di depan sidang paripurna DPRD; 
Disamping itu, penelitian ini juga menemukan bahwa terdapat sejumlah faktor yang mempengaruhi fungsi pengawasan DPRD terhadap kinerja pemerintah daerah mencakup: kemampuan dan kecakapan anggota DPRD secara individu dalam memahami berbagai aturan dan kebijakan serta regulasi yang ada, ketersediaan sarana dan prasarana serta fasilitas kantor yang memadai dan ketepatan waktu dalam melakukan pemeriksaan dan pengujian data guna kepentingan penyelidikan terhadap adanya dugaan pelanggaran yang dilakukan oleh eksekutif.

\section{Daftar Pustaka}

Jones. Charles 0. 1991. Pengantar Kebijakan Publik (Public Policy). Terjemahan Nashir Budiman. Cetakan Pertama. Jakarta: Rajawali

David Easton, 1973: Public Policy is the Authoritative allocation of values for the whole society

Dunn N. William. 2000 : Analisis Kebijakan Publik. Hanindita. Yogyakarta

Marbun, B.N. 1994. DPRD: Pertumbuhan, Masalah, dan Masa Depannya (Edisi Revisi). Jakarta: Penerbit Erlangga

Ndraha Taliziduhu, 1990. Pembangunan Masyarakat Mempersiapkan Masyarakat Tinggal Landas. Bina Aksara. Jakarta

Salang, Sebatian, dkk. 2009. Potret Partai Politik Indonesia. Forum Politisi. Jakarta
Sarwoto, 2010. Dasar-Dasar Organisasi dan Manajemen. Ghalia Indonesia. Jakarta

Sujamto, 1990. Aspek-Aspek Pengawasan di Indonesia. Sinar Grafika. Jakarta

Sugiyono, 2008. Metode Penelitian Kuantitatif, Kualitatif, dan $R \& D$. Alfabeta. Bandung

Siagian, Sondang P. 1997. Teori Pengembangan Organisasi. Bina Aksara. Jakarta

Schemerson, Sule dan Saefullah. 2005. Pengawasan Kinerja Birokrasi dalam Perubahan Politik Indonesia. Universitas Brawijaya Malang

\section{Dokumen:}

Undang-Undang No. 22 Tahun 2003, Tentang Susunan dan Kedudukan MPR, DPR, DPD, dan DPRD

Undang-Undang No. 23 Than 2014 Tentang Pemerintahan Daerah

Peraturan Pemerintah No. 58 Tahun 2005 Tentang Pengelolaan Keuangan Daerah

Kepmendagri No. 29 Tahun 2002 Tentang Penyusunan Arah Kebijakan Umum APBD. 